\title{
The Parallel Between Non-removal of Asylum Seekers and Non-execution of a European Arrest Warrant on Human Rights Grounds: The CJEU Case of N.S. v. Secretary of State for the Home Department
}

\author{
Fenella Billing*
}

\begin{abstract}
The European Court of Human Rights and the Court of Justice of the EU have recently considered the principle of 'mutual trust', in the context of transferring asylum seekers between EU Member States under the Dublin Regulation of 2003. Both of the courts have found that Member States may not assume, conclusively, that other Member States will guarantee fundamental and international human rights obligations. It has been decided that such a conclusive presumption is in violation, inter alia, of the Charter of Fundamental Rights of the EU and the European Convention on Human Rights and Fundamental Freedoms. Following the decision of the CJEU, the presumption of mutual trust must be regarded as being rebuttable. This article examines the application of the judgment on asylum from the CJEU to the situation of surrender under the EAW Framework Decision. Specifically, the article proposes that it is necessary to explicitly implement a rebuttable presumption in the EAW Framework Decision, and in national implementing legislation, which will enable the question to be raised in the executing court prior to a European Arrest Warrant being executed as to whether the issuing state is in a position to respect and protect fundamental and international human rights.
\end{abstract}

\section{Introduction}

On 21 January 2011, in M.S. S. v. Belgium and Greece, ${ }^{1}$ the European Court of Human Rights (the Strasbourg Court) concluded that Belgium was in violation of Article 3 of the European Convention on Human Rights and Fundamental Freedoms (ECHR), which prohibits torture, inhuman or degrading treatment or punishment. ${ }^{2}$ Belgian refugee authorities had transferred an asylum seeker to Greece when it was well documented at the time that the conditions of reception in Greece, including detention, were "degrading" and not compatible with Greece's obligations under the ECHR and international law. ${ }^{3}$

\footnotetext{
* The author is a Ph. D. candidate at the University of Southern Denmark. The author would like to acknowledge the assistance of Professor Thomas Elholm of the University of Southern Denmark.

${ }^{1}$ European Court of Human Rights (ECtHR), M. S. S. v. Belgium and Greece, Application no. 30696/09, Judgment 21 January 2011.

${ }^{2}$ Both countries were also found to be in violation of Article 13 of the European Convention for the Protection of Human Rights and Fundamental Freedoms (ECHR), CETS 005, opened for signature on 4 November 1950, entered into force 3 September 1953.

${ }^{3}$ ECtHR, M.S. S. v. Belgium and Greece (fn. 1), margin no 161-166, 194-195, 365-368. In this case, reports and other documents detailing the poor conditions of reception and detention had been received from a range of sources, including: the European Committee for the Prevention of Torture (CPT); Council of Europe Commissioner for Human Rights; United Nations High Commissioner for Refugees (UNHCR); Amnesty International; and Human Rights Watch.
} 
Significantly, this issue has been raised once again - this time in the Court of Justice of the European Union (CJEU). ${ }^{4}$ In the case of N.S. v. Secretary of State for the Home Department (the CJEU asylum case) ${ }^{5}$ the CJEU delivered its judgment on 21 December 2011. The Court concluded that Member States of the EU may not render an asylum applicant to another Member State, which has primary responsibility under EU asylum legislation, in the event that there are systemic deficiencies in that Member State that give rise to substantial grounds for believing that there is a real risk that the asylum seeker's fundamental and human rights, namely, the right to human dignity (Article 1), the prohibition on torture and other forms of illtreatment (Article 4), the right to asylum (Article 18) and the right to an effective remedy and to a fair trial (Article 47) under the Charter of Fundamental Rights of the European Union (the Charter), ${ }^{6}$ will be violated. This prohibition on transferring asylum seekers applies if the Member State where the applicant lodges the application knows or ought to know about the deficiencies. ${ }^{7}$

What do these judgments tell us about the obligation of the judge in the executing state, when considering whether or not to execute a European Arrest Warrant (EAW), authorising the surrender of suspects, or criminals fleeing from punishment, to another EU Member State?

The EU requirement of mutual trust between Member States seems to suggest that the execution of an EAW cannot be refused on the grounds of human rights. For example, in 2009, a British citizen, Andrew Symeou, appealed to the High Court of Justice in the UK, against the execution of an EAW issued by a Greek court. Symeou alleged that the Greek police had extracted witness statements through violence and intimidation, manipulated other evidence and relied on an unlawfully issued domestic arrest warrant. Despite concerns regarding an absence of investigation into Symeou's allegations, the High Court of Justice in the UK dismissed his appeal against the execution of an EAW.

\footnotetext{
${ }^{4}$ See also Plaintiff M70/2011 v. Minister for Immigration and Citizenship; Plaintiff M106 of 2011 v. Minister for Immigration and Citizenship [2011] HCA 32 (31 August 2011), in which, on very similar grounds, the High Court of Australia condemned the transfer of asylum seekers, who had arrived unlawfully on Australian territory by boat, to have their applications determined in Malaysia under an agreement between the Australian and Malaysian governments.

${ }^{5}$ Court of Justice of the European Union (CJEU) 21. 12. 2011, case C-411/10 (N.S. v. Secretary of State for the Home Department (England and Wales)) [2011] not yet published. This case has been joined with Court of Justice of the European Union (CJEU) 21. 12. 2011, case C-493/10 (M.E. v. Refugee Applications Commissioner, Minister for Justice, Equality and Law Reform (Republic of Ireland)), which deals with the transfer of asylum seekers from Ireland to Greece under the Dublin Regulation.

${ }^{6}$ Charter of Fundamental Rights of the European Union, OJ 2007 L303/01.

${ }^{7}$ Article 6 (right to liberty and security), Article 7 (right to respect for private life) and Article 19 (protection of those facing removal, expulsion or extradition against being ill-treated), among other rights, are also relevant in the context of extradition and detention: Charter of Fundamental Rights of the European Union, OJ 2007 L303/01. In the application of EU law, the CJEU stated that scope of protection offered by EU law, and in particular Articles 1, 18 and 47 of the Charter, is not different to that conferred upon an asylum applicant by Article 3 of the ECHR. The CJEU's judgment confirms the view expressed in the Advisory Opinion of the Advocate General in the case that the Charter may not provide any less protection of fundamental rights than the ECHR; it also highlights the importance of considering case-law from the Strasbourg Court when determining issues under the Charter: CJEU, N.S. $v$. Secretary of State for the Home Department (England and Wales) (fn. 5), margin no 88-91; and Court of Justice of the European Union (CJEU), Opinion of Advocate General Trstenjak, 22. 9. 2011, margin no 143-148.
} 
While warning that the consequences of the Framework Decision may be a matter of legitimate debate and concern, the High Court of Justice emphasised that "...the common area for judicial decisions means that the judicial systems of the countries of the European Union must be regarded as capable of providing sufficient minimum safeguards for a fair trial in a civilised country..." However, according to statistics held by the Strasbourg Court, 'violation judgments' of Article 6 of the ECHR, recorded between 1959 and 2010, represent more than 50 per cent of all violation judgments against 18 out of 27 EU Member States. A large proportion of these judgments relate to complaints about the length of proceedings.

Moreover, between December 2005 and June 2010, the Strasbourg Court found there had been violations of Article 3 by a number of EU Member States, based on evidence of threats and actual violence, lack of medical treatment and of overcrowded, unsanitary or otherwise inappropriate conditions or practices experienced by detainees while in police or prison detention. ${ }^{10}$ These types of cases might support a claim against the execution of an EAW, particularly where they deal with deep-seated, recurring issues such as ill-treatment, overcrowding and other related problems in Greek or Polish detention centres and prisons. Problems such as overcrowding can constitute degrading treatment, even in the absence of any intention to degrade on the part of the authorities. ${ }^{11}$ The Strasbourg Court has long recognized that extraditing a person to a state where there is a risk that their human rights will be violated may constitute a breach of the ECHR. ${ }^{12}$

In reference to the case of M.S.S.v. Belgium and Greece, ${ }^{13}$ Peers has questioned the validity of the "near-absolute rule of mutual trust" in Justice and Home Affairs (JHA) cooperation and suggests that more resources should be applied to securing human rights in the 'area of freedom, security and justice'. ${ }^{14}$ This article will

\footnotetext{
${ }^{8}$ Andrew Symeou v. Public Prosecutor's Office at the Court of Appeals, Patras, Greece [2009] EWHC 897 (Admin), 1 May 2009, margin no. 39. After almost a year in pre-trial detention, Andrew Symeou was acquitted by the Greek courts in June 2011. See further, Fair Trials International Annual Review 2010 - 2011, http://issuu.com/fairtrialsinternational/docs/fti-annual-review-single? mode $=$ window at 2 December 2011.

${ }^{9}$ European Court of Human Rights, Statistics 1959 - 2010: Statistics on judgments by State (Provisional Edition) September 2011, www.echr.coe.int at 15 December 2011.

${ }^{10}$ See European Court of Human Rights (ECtHR), Bekos and Koutropoulos v. Greece, Application no. 15250/02, Judgment 13 December 2005; Jalloh v. Germany, Application no. 54810/00, Judgment 11 July 2006; Frerot v. France, Application no. 70204/01, Judgment 12 June 2007; Renolde v. France, Application no. 5608/05, Judgment 16 October 2008; Slawomir Musial v. Poland, Application no.28300/06, Judgment 20 January 2009; Sulejmanovic v. Italy, Application no. 22635/03, Judgment 16 July 2009; Norbert Sikorski v. Poland, Application no. 17599/05, Judgment 22 October 2009; Orchowski v. Poland, Application no. 17885/04, Judgment 22 October 2009; Gäfgen v. Germany, Application no. 22978/05, Judgment 1 June 2010. See also the Haidn v. Germany, Application no. 6587/04, Judgment 13 January 2011, in relation to a violation of Article 5(1) (right to liberty and security). The obligations contained in the Council of Europe 1987 Convention for the Prevention of Torture and Inhuman or Degrading Treatment or Punishment, among other treaties, and the recommendations contained in the 2006 European Prison Rules, also apply to all EU Member States. See, for example, the $19^{\text {th }}$ General Report and various country reports of the Committee for the Prevention of Torture (CPT), dealing in part with prison overcrowding.

${ }^{11}$ ECtHR, Orchowski v. Poland (fn. 10).

${ }^{12}$ European Court of Human Rights (ECtHR), Soering v. United Kingdom, Application no. 14038/88, Judgment 7 July 1989.

${ }^{13}$ ECtHR, M. S. S. v. Belgium and Greece (fn. 1).

${ }^{14}$ S. Peers, Mission Accomplished? EU Justice and Home Affairs Law After the Treaty of Lisbon, Common Market Law Review (CML Rev.) 2011, pp. 692-693.
} 
examine the principles recently established by the CJEU in the asylum case, and the applicability of those principles to surrender in accordance with 'mutual recognition' under the EAW Framework Decision of 13 June 2002. ${ }^{15}$

\section{The CJEU Asylum Case}

When asylum matters were transferred to the EC (with the exception of Denmark) under the Treaty of Amsterdam in 1997, Article 63(1) of the Treaty establishing the European Community (TEC) provided that harmonisation of national laws in asylum matters should be limited to establishing minimum standards, which were to be settled in accordance with relevant international treaties, including the ECHR. ${ }^{16}$ On this primary law basis, and as part of a Common European Asylum System, four secondary law 'directives' dealing with minimum standards for treatment of, and examination of claims by, asylum seekers have been adopted. The preambles of these directives all recognise respect for fundamental rights, complying with the principles established in the Charter and the obligations of Member States under international law. ${ }^{17}$

The Dublin Regulation of $2003^{18}$ was intended to establish a fair and effective common asylum system in the EU, to rationalise the examination of asylum applications, to prevent forum shopping by asylum seekers, and to protect those legitimately seeking protection. ${ }^{19}$ With the lack of internal border control within the EU, third country nationals were frequently being recorded as entering into a number of different countries before lodging an asylum application in a particular jurisdiction. One of the goals of the Common European Asylum System has been to distribute the burden associated with immigration in an effective manner. The main purpose of the Regulation is to rapidly determine which EU Member State will bear the responsibility for examining an application, as a way to ensure effective access to asylum procedures across the EU (Recital 3). ${ }^{20}$

There is no specific reference to the treatment of asylum seekers in the Regulation. However, the preamble of the Regulation does refer to the application of the Geneva Convention and the principle of non-refoulement (Recital 2), the importance of family unity for asylum seekers (Recitals 6 and 7) and to fairness for Member States and asylum seekers (Recital 4). Significantly, due to the interaction

\footnotetext{
${ }^{15}$ Council Framework Decision of 13 June 2002 on the European arrest warrant and the surrender procedures between Member States, OJ 2002 L 190/1.

${ }^{16}$ Following the entry into force of the Lisbon Treaty in December 2009, and the removal of a 'minimum standards' clause, EU legislation may now aim to fully harmonize asylum law: S. Peers, EU Justice and Home Affairs Law (3rd ed.), 2011, p. 308.

${ }^{17}$ CJEU, N. S. v. Secretary of State for the Home Department (England and Wales) (fn. 5), margin no 11-15.

${ }^{18}$ Regulation (EC) No 343/2003 ('the Dublin Regulation'). This Regulation, also known as the 'Dublin II Regulation', replaced the 1990 Dublin Convention between Member States, with the exception of Denmark. See CJEU, N. S. v. Secretary of State for the Home Department (England and Wales) (fn. 5), margin no 9.

${ }^{19}$ See preamble Recitals 3 and 4, Regulation (EC) No 343/2003 (the Dublin Regulation) and CJEU, N. S. v. Secretary of State for the Home Department (England and Wales) (fn. 5), margin no 79 and 84.

${ }^{20}$ See preamble Recital 3, Regulation (EC) No 343/2003 (the Dublin Regulation).
} 
between the Regulation, the directives and the obligations of Member States under international law, it is legally ensured that the treatment of asylum seekers in each Member State complies with the Charter, the Geneva Convention and the ECHR. ${ }^{21}$ Further, Article 78 of the TFEU and Article 18 of the Charter provide for the right to asylum with due respect for the Geneva Convention and the 1967 Protocol. $^{22}$

However, the Regulation does not provide an express provision that deals with the situation where the asylum system in a particular Member State becomes overburdened. In relation to Greece, the CJEU accepted that, by reason of its geographical location as an entry point to the EU, the large number of asylum seekers for whom it was primarily responsible had exceeded the capacity of the system. ${ }^{23}$ In the judgment, the CJEU referred to the decision of the Strasbourg Court in M.S.S.v. Belgium and Greece, ${ }^{24}$ which in turn refers to a number of reports by United Nations and non-governmental organisations, judgments of national courts from individual Member States and the findings of fact reproduced by the referring court, as providing a clear indication of the urgency of the asylum situation in Greece. The Strasbourg Court acknowledged that a number of reports highlighted the practical difficulties of applying the Dublin system in Greece. ${ }^{25}$ In practice, the result was that the Greek authorities could no longer treat asylum seekers and their applications in accordance with their obligations in relation to the minimum standards contained in a number of EU directives, the Charter or international law. $^{26}$

On 12 July 2010, against the background of the present crisis affecting the Greek asylum system, the Court of Appeal of England and Wales (UK) referred the asylum case to the CJEU. Having left Afghanistan, the asylum seeker travelled through a number of countries, including Greece, where he was arrested on 24 September 2008 and detained for four days. He did not claim asylum, was ordered to leave Greece, and was expelled to Turkey. Having escaped from detention in Turkey he arrived in the UK and applied for asylum on 12 January 2009. In the referring court, the asylum seeker brought a claim for judicial review of the Secretary of State's decision to transfer him back to Greece under the Dublin Regulation. The Secretary of State found that the asylum seeker's claim, that removal to Greece would be contrary to his rights under the ECHR, was unfounded. The asylum seeker has been challenging his transfer from the UK to Greece based on the conditions of reception of asylum seekers in Greece (including conditions in deten-

\footnotetext{
${ }^{21}$ CJEU, N. S. v. Secretary of State for the Home Department (England and Wales) (fn. 5), margin no 15, 76-80; see also the Advisory Opinion of the Advocate General in the same case, margin no. 96.

${ }^{22}$ CJEU, N. S. v. Secretary of State for the Home Department (England and Wales) (fn. 5), margin no 10 and 75.

${ }^{23}$ CJEU, N. S. v. Secretary of State for the Home Department (England and Wales) (fn. 5), margin no 87.

${ }^{24}$ ECtHR, M. S. S. v. Belgium and Greece (fn. 1). See CJEU, N.S. v. Secretary of State for the Home Department (England and Wales) (fn. 5), margin no $88-90$.

${ }^{25}$ ECtHR, M. S. S. v. Belgium and Greece (fn. 1), margin no. 347-350.

${ }^{26}$ CJEU, N. S. v. Secretary of State for the Home Department (England and Wales) (fn. 5), margin no 81; see also CJEU, Opinion of Advocate General Trstenjak (fn. 7), margin no 99-105.
} 
tion and outside of detention), the lack of effective procedures for the determination of the merits of asylum applications and the risk of refoulement to Afghanistan. ${ }^{27}$

The referring court sought a preliminary ruling to clarify the extent of the UK's human rights obligations, in particular under the Charter, when applying the Dublin Regulation to the transfer of asylum seekers back to the Member State with primary responsibility under the Regulation. ${ }^{28}$ This will usually involve removal to the Member State where the asylum seeker initially entered the EU. Specifically, the referring court sent the case to the CJEU to determine, inter alia, whether a Member State's duty to observe EU fundamental rights, such as the rights contained in Articles 1, 4, 18, 19(2) (the right to protection in the event of removal, expulsion or extradition) and 47 of the Charter, is discharged where this State is transferring the asylum seeker to the Member State which is identified as having primary responsibility under the Regulation, regardless of the asylum situation in that other Member State. In other words, is the Member State who is transferring the asylum seeker obliged to assess the compliance with fundamental rights and EU asylum obligations by the primarily responsible Member State ${ }^{29}$

The CJEU found in the affirmative stating that, if there are substantial grounds for believing that there are systemic problems in the asylum procedure and the conditions of reception in the responsible Member State, resulting in inhuman or degrading treatment of asylum seekers in that Member State, the transfer of an asylum seeker would be incompatible with Article 4 of the Charter, for example. ${ }^{30}$ The duty of a Member State to observe fundamental EU rights will not be discharged simply because an asylum seeker is being returned to another Member State in accordance with the Dublin Regulation. Where a Member State knows, or ought to know, that there is a real risk of violation of Article 4 of the Charter in another Member State, then a transfer under the Dublin Regulation is prohibited. ${ }^{31}$ The same would apply in relation to Articles 1, 18 and 47 of the Charter. ${ }^{32}$

However, not every infringement of a fundamental right or EU asylum legislation, by the Member State with primary responsibility, will prevent the transfer of an asylum seeker. ${ }^{33}$ The CJEU found that, if the transfer of an asylum seeker under the Regulation was mandatorily prevented by the slightest infringement, by the responsible Member State, of the Charter or one of the four asylum directives, for example, this result would deprive the obligations created by the EU asylum legislation of their substance and purpose. ${ }^{34}$

${ }^{27}$ CJEU, N. S. v. Secretary of State for the Home Department (England and Wales) (fn. 5), margin no 34-45.

${ }^{28}$ CJEU, N. S. v. Secretary of State for the Home Department (England and Wales) (fn. 5), margin no 50.

${ }^{29}$ CJEU, N. S. v. Secretary of State for the Home Department (England and Wales) (fn. 5), margin no 70-71.

${ }^{30}$ CJEU, N. S. v. Secretary of State for the Home Department (England and Wales) (fn. 5), margin no 86. In addition, the CJEU found that a national law which operates a conclusive presumption that a Member State is a safe country where asylum seekers are not exposed the risk of being returned to a third persecuting State, is incompatible with Article 47 (right to a fair trial and right to an effective remedy) of the Charter: margin no 101.

${ }^{31}$ CJEU, N. S. v. Secretary of State for the Home Department (England and Wales) (fn. 5), margin no 92 and 94.

32 The Court decided that Articles 1, 18 and 47 of the Charter do not lead to a different answer to the issues raised. The Court did not specifically mention whether Article 19(2) would also lead to a similar conclusion: margin no 114.

${ }^{33}$ CJEU, N. S. v. Secretary of State for the Home Department (England and Wales) (fn. 5), margin no 82-85.

${ }^{34}$ CJEU, N. S. v. Secretary of State for the Home Department (England and Wales) (fn. 5), margin no 82-85. 
If the Member State applying the Dublin Regulation is prevented from transferring an asylum seeker to the Member State with primary responsibility, that Member State must continue to examine the criteria set out in the Regulation to determine whether another Member State will be responsible, or whether it should accept responsibility, for the application. ${ }^{35}$

\section{The Framework Decision on the European Arrest Warrant}

The EAW Framework Decision (the Framework Decision) ${ }^{36}$ is a secondary EU legal instrument that was created under the former third pillar and adopted in 2002, pursuant to Title VI of the Treaty on European Union (TEU). ${ }^{37}$ Therefore, a decision in relation to an EAW by an issuing or executing judge is a national implementing decision of EU law for the purposes of Article 51(1) of the Charter. ${ }^{38}$

Following the conclusions of the Tampere European Council of 15 and 16 October 1999, and in pursuance of the objective of creating an 'area of freedom, security and justice' within the EU, the Framework Decision abolishes formal extradition between Member States and replaces it with a more simplified and faster system of surrender by a judicial authority in the executing state, which implements the principle of 'mutual recognition'. In general terms, an EAW is executed directly, without the requirement of an intermediate check into its validity, while respecting fundamental and international human rights. ${ }^{39}$ Recital ten reiterates that " $[\mathrm{t}] \mathrm{he}$ mechanism of the European arrest warrant is based on a high level of confidence between Member States". ${ }^{40}$ In particular, when assessing whether or not to execute an EAW and surrender a person to another Member State, Article 1(2) requires the executing judicial authority to base the decision on "...the principle of mutual recognition and in accordance with the provisions of the Framework Decision". 41

Human rights arguments are not explicitly grounds for mandatory or optional non-execution of an EAW. ${ }^{42}$ However, under the heading of defining the EAW and the obligation to execute it, Article 1(3), together with Recital 12, of the Framework Decision emphasises the need, and even the obligation, to respect fundamental

\footnotetext{
${ }^{35}$ CJEU, N. S. v. Secretary of State for the Home Department (England and Wales) (fn. 5), margin no 96-97.

${ }^{36}$ Council Framework Decision of 13 June 2002 on the European arrest warrant and the surrender procedures between Member States, OJ 2002 L 190/1.

${ }^{37}$ Ex Article 31(a) and (b) and 34(2)(b) of the Treaty on European Union (TEU); see further Art 82(1)(a) and (b) Treaty on the Functioning of the European Union (TFEU).

${ }^{38}$ Charter of Fundamental Rights of the European Union, OJ 2007 L303/01. See also CJEU, N. S. v. Secretary of State for the Home Department (England and Wales) (fn. 5), margin no 68 and 77.

${ }^{39}$ First, fifth and sixth Recitals of the Council Framework Decision of 13 June 2002 on the European arrest warrant and the surrender procedures between Member States, OJ 2002 L 190/1. See also J. Ouwerkerk, Quid Pro Quo? A Comparative Law Perspective on the Mutual Recognition of Judicial Decision in Criminal Matters, 2011, p. 112.

${ }^{40}$ Recital 10, Council Framework Decision of 13 June 2002 on the European arrest warrant and the surrender procedures between Member States, OJ 2002 L 190/1.

${ }^{41}$ Article 1(2), Council Framework Decision of 13 June 2002 on the European arrest warrant and the surrender procedures between Member States, OJ 2002 L 190/1.

${ }^{42}$ See Articles 3 and 4, Council Framework Decision of 13 June 2002 on the European arrest warrant and the surrender procedures between Member States, OJ 2002 L 190/1.
} 
and human rights. Particular reference is made to the Charter, and to the principles enshrined in Article 6 of the TEU. Article 6(1) establishes the Charter as EU primary law and Article 6(3) recognises the rights guaranteed by the ECHR as general principles of Union law. Specifically, in Recital 13, the Framework Decision expressly prohibits the removal, expulsion or extradition of a person to a State where there is a serious risk that they will be subjected to the death penalty, torture or some other form of inhuman or degrading treatment or punishment.

Reading these provisions in combination, it appears that the executing judge's obligation to execute an EAW on the basis of mutual recognition presupposes that (in addition to the issuing judge) the executing judge should consider the validity of the EAW on human rights grounds. For example, an executing judge may be entitled, or even obliged, to refuse to execute an EAW, because substantial evidence has been presented supporting the finding of a real risk that the requested person will suffer inhumane conditions of detention.

It is arguable that fundamental rights grounds for non-execution of an EAW “... stem from the primary law of the EU", 43 which takes precedence over the Framework Decision. Peers has reported that a series of opinions of Advocates General have concluded that Member States can refuse to recognise EAWs on human rights grounds. ${ }^{44}$ However, this is still a controversial issue and remains unresolved in the implementation of the Framework Decision at a national level. ${ }^{45}$

In the case of Szymon Kozlowski, the Court of Justice reiterated that an executing judicial authority can only oppose surrender on one of the mandatory or optional grounds for refusal provided for in the Framework Decision. ${ }^{46}$ However, the Court did not define or expand on the general requirement in Article 1(2) that the executing authority's decision about surrender must be "in accordance with the provisions of the Framework Decision”. Pursuant to Article 1(3), these provisions do not modify the obligation to respect fundamental rights.

Court of Justice case-law establishes that the Framework Decision has 'indirect effect', the purpose being to encourage a 'conforming interpretation' by national courts of national implementing laws. ${ }^{47}$ The Commission, in the 2007 and 2011 Reports, has criticised Member States' implementation of Article 1(3) and Recitals 12 and 13 (in relation to conformity with fundamental rights) as being 'mixed', with a number of Member States implementing the Framework Decision by including human rights as a mandatory ground for non-execution. ${ }^{48}$ In particular, Denmark

\footnotetext{
43 Peers (fn. 16), pp. $709-710$.

${ }^{44}$ Peers (fn. 16), p. 709.

${ }^{45}$ See Commission of the European Communities, Commission Staff Working Document, Annex to the Report from the Commission on the implementation since 2005 of the Council Framework Decision of 13 June 2002 on the European arrest warrant and the surrender procedures between Member States [COM (2007) 407], SEC(2007) 979, 11 July 2007,5 .

${ }_{46}$ Court of Justice (ECJ) 17. 7. 2008, case C-66/08 (Szymon Kozlowski), margin no 43.

${ }^{47}$ Court of Justice (ECJ) 16. 6. 2005, case C-105/03 (Maria Pupino), margin no 31-43.

${ }^{48}$ Commission of the European Communities, Commission Staff Working Document, Annex to the Report from the Commission on the implementation since 2005 of the Council Framework Decision of 13 June 2002 on the European arrest warrant and the surrender procedures between Member States [COM (2007) 407], SEC(2007) 979, 11 July 2007, 5; European Commission, Report from the Commission to the European Parliament and the Council on
} 
has been criticised for its implementation of the Framework Decision, whereby the Danish law requires that surrender is refused on the ground that there is a risk of torture, degrading treatment, violation of due process, or if the surrender appears to be unreasonable on humanitarian grounds. In its report, the Commission argued that provisions such as these go beyond the Framework Decision and Member States' discretion in its implementation.

However, it is significant that in the 2011 Report, the Commission acknowledges that deficiencies in some prisons within the EU have been raised in the Strasbourg Court. The Commission has gone so far as to state that the EAW Framework Decision does not require an executing judicial authority to surrender a requested person if satisfied:

'...taking into account all the circumstances of the case, that such surrender would result in a breach of the requested person's fundamental rights arising from unacceptable detention conditions.. ${ }^{49}$

In addition, the Commission recommends that, in transposing and applying the Framework Decision, Member States should adopt and implement the measures arising from the roadmap in relation to protecting procedural rights of suspected or accused persons. The Commission is of the view that, in doing so, Member States will reinforce the mutual trust that is imperative to the future success of the EAW instrument. ${ }^{50}$

\section{Application of the CJEU Asylum Case to surrender under the EAW Framework Decision}

\section{Creation of an area of freedom, security and justice within the EU}

Both asylum and extradition can involve the removal of a person from one state to another. Therefore, the fundamental and human rights of the person involved are central in both situations. ${ }^{51}$ Article $19(2)$ of the Charter, which provides that noone may be removed, expelled or extradited to a State where there is a serious risk that they will face the death penalty, torture or other inhuman or degrading treatment or punishment, gives a clear example of this similitude. Many of the sources that are used to inform courts about asylum are also relevant to extradition; and an asylum application may even have an impact on an extradition hearing. ${ }^{52}$

the implementation since 2007 of the Council Framework Decision of 13 June 2002 on the European arrest warrant and the surrender procedures between Member States [SEC (2011) 430], COM [2011] 175, 11 April 2011, p. 5.

${ }^{49}$ European Commission, Report from the Commission to the European Parliament and the Council on the implementation since 2007 of the Council Framework Decision of 13 June 2002 on the European arrest warrant and the surrender procedures between Member States [SEC (2011) 430], COM [2011] 175, 11 April 2011, p. 7.

${ }^{50}$ European Commission, Report from the Commission to the European Parliament and the Council on the implementation since 2007 of the Council Framework Decision of 13 June 2002 on the European arrest warrant and the surrender procedures between Member States [SEC (2011) 430], COM [2011] 175, 11 April 2011, p. 9.

${ }^{51} J o n e s$ et al (eds), Extradition and Mutual Legal Assistance Handbook (2nd ed.), 2010, p. 91.

52 Jones et al (fn. 51), pp. 95 and 97. 
The EAW Framework Decision is the first criminal justice instrument that implements the principle of 'mutual recognition' of judicial decisions as the cornerstone of judicial cooperation. ${ }^{53}$ On the other hand, decisions made by Member States applying the Dublin Regulation do not expressly implement 'mutual recognition'. However, the Dublin Regulation asserts the 'mutual obligations' of Member States, ${ }^{54}$ by laying down the criteria used to determine responsibility to examine asylum applications and by confirming respect for fundamental rights and principles. ${ }^{55}$ The CJEU confirmed that the Common European Asylum System is based on "mutual confidence" that all participating states observe fundamental rights and a "presumption of compliance" with EU law. ${ }^{56}$ Article 4 of the TEU, which refers to the 'principle of sincere cooperation', also known as the enforcement principle, whereby Member States have a general obligation to enforce EU law, may also be relevant here. ${ }^{57}$ Sincere cooperation between Member States is necessary to ensure that enforcement of EU law, including human rights provisions, has a practical and workable effect.

The principle of mutual recognition is not unique to EU criminal justice and originates as a former first pillar principle that was 'used to unblock the single market' and enhance free movement of goods. ${ }^{58}$ The areas of Justice and Home Affairs dealing with asylum and immigration were moved to the First Pillar by the operation of the Treaty of Amsterdam (TFEU) in 1997. ${ }^{59}$ Cooperation between Member States in these areas has been necessary as a result of extending the right to freedom of movement of EU citizens, to third state nationals. ${ }^{60}$ The principle of mutual recognition was transferred to judicial cooperation in criminal matters at the intergovernmental level under the 'Third Pillar' prior to the Lisbon Treaty.

Freedom of movement within the EU has allowed third state nationals and criminals to move easily from one EU state to another, and for organised criminal groups to consolidate. ${ }^{61}$ Article 2 of the EU Treaty ${ }^{62}$ bases the creation of an area of freedom, security and justice on assuring freedom of movement of persons in conjunction with implementing "...appropriate measures with respect to external border controls, asylum, immigration and the prevention and combating of crime" (emphasis added).

It is not surprising that the Dublin Regulation and the EAW Framework Decision both stem from the 1999 Tampere conclusions reached by the European Council when discussing freedom of movement and border controls within the EU,

\footnotetext{
${ }^{53}$ Art 1(2) and (3). See also Ouwerkerk (fn. 39), p. 112.

${ }^{54}$ B. Daniel, T. Elholm, P. Starup and M. Steinicke, Grundlæggende EU-Ret: EU Efter Lissabontraktaten, 2011, p. 590.

55 See Recital 15 and Art 1 Dublin Regulation.

${ }_{56}$ CJEU, N. S. v. Secretary of State for the Home Department (England and Wales) (fn. 5), margin no 78 and 83.

${ }^{57}$ See further André Klip, European Criminal Law, 2009, p. 16.

58 Ouwerkerk (fn. 39), p. 54. See further Daniel et al (fn. 54), p. 42.

${ }^{59}$ Daniel et al (fn. 54), p. 589.

${ }^{60}$ Ouwerkerk (fn. 39), p. 54. See further Daniel et al (fn. 54), pp. 589 and 596.

${ }^{61}$ Presidency Conclusion, Tampere European Council, 15 and 16 October 1999, http://www.europarl.europa.eu v. Summits/tam_en.htm , at 12 December 2011. See further Ouwerkerk (fn. 39), p. 2.

${ }^{62}$ Treaty on European Union, 7 February 1992, consolidated version, OJ 2002, C325/1.
} 
in connection with the creation of an area of freedom, security and justice. The Tampere conclusions state that European integration is grounded upon a commitment to freedom, to be enjoyed in conditions of security and justice, which is based on human rights, democracy and the rule of law. Therefore, the conclusions relating to asylum and immigration (and the development of a Common European Asylum System), and to enhanced cooperation in law enforcement in cross-border cases, similarly aim at effective convergence of legal systems and setting common minimum standards, including fair, accessible and efficient procedures and conditions. ${ }^{63}$

The Dublin Regulation and the EAW Framework Decision are both illustrative of these freedom, security and justice objectives. It is assumed that Member States implementing and interpreting EU asylum or surrender provisions, do so in a manner which is consistent with the fundamental and human rights guaranteed by the Charter, the ECHR and other sources of international law. ${ }^{64}$ This is evident from the CJEU's rendering of the Dublin Regulation in the asylum case, just as it is clear from the text of the EAW Framework Decision. There is a positive 'protective' purpose to the fundamental rights that are expressly or inherently contained in Articles 1, 4 and 19(2) of the Charter. ${ }^{65}$

The principle of mutual recognition, acknowledging Member States' right to be different, is based on 'mutual trust', rather than harmonisation of national laws. ${ }^{66}$ In the context of the internal market and free movement of goods, mutual trust means that if goods are placed legally on the market in one Member State, other Member States trust that Union law has been complied with and are prohibited from subjecting those goods to further checks. ${ }^{67}$. In relation to free movement of persons, and the acceptable limitations on that freedom, cooperation between states is built upon trust in each other's legal and political systems and a shared confidence in the level of fundamental and human rights protection offered by each state. ${ }^{68}$ Mutual trust rests upon a presumption that all Member States meet international human rights standards. ${ }^{69}$ This can be said of cooperation between states in asylum policy and practice, as well as in surrender and extradition, in the creation of an area of freedom, security and justice. ${ }^{70}$ Asylum and surrender in the EU can be regarded as parallel legal areas, with parallel legal objectives stemming from EU law.

\footnotetext{
${ }^{63}$ See Recital 2 of Regulation (EC) No 343/2003 ('the Dublin Regulation') and Recital 1 of Council Framework Decision of 13 June 2002 on the European arrest warrant and the surrender procedures between Member States, OJ 2002 L 190/1 (EAW Framework Decision). See further Presidency Conclusion, Tampere European Council, 15 and 16 October 1999, http://www.europarl.europa.eu v. Summits/tam_en.htm , at 12 December 2011. See further Ouwerkerk (fn. 39), p. 112.

${ }^{64}$ CJEU, N. S. v. Secretary of State for the Home Department (England and Wales) (fn. 5), margin no 78-80. See also $S$. Peers, Court of Justice: The NS and ME Opinions - The Death of "Mutual Trust"? , 2011, http://www.statewatch. org/analyses/no-148-dublin-mutual-trust.pdf at 15 December 2011.

${ }^{65}$ See CJEU, Opinion of Advocate General Trstenjak (fn. 7), margin no 112.

${ }^{66}$ Ouwerkerk (fn. 39), pp. 112 and 270. Klip (fn. 57), pp. 23 and 31.

${ }^{67} \mathrm{Klip}$ (fn. 57), p. 93

${ }^{68}$ A. Suominen, The principle of mutual recognition in cooperation in criminal matters, 2011, p. 46; Klip (fn. 57), pp. 93-95.

${ }^{69}$ Ouwerkerk (fn. 39), p. 112.

${ }^{70}$ Peers (fn. 64).
} 
Whether absolute mutual trust actually exists is not always evident in practice. $^{71}$ Absolute mutual trust between Member States, being an unquestioning belief in the compliance by other states with fundamental human rights, does not allow public decision makers to take into account when extraordinary circumstances apply, such as the crisis impeding the Greek asylum system.

\section{The operation of a conclusive presumption that other Member States observe fundamental rights}

It is highly relevant, in connection with discourse about the EAW system, that the CJEU found that the obligation to observe fundamental rights under the Dublin Regulation precludes the operation of a conclusive presumption, that the Member State with primary responsibility to examine an asylum application will, in practice, observe the asylum seeker's fundamental rights under EU law. In the opinion of Advocate General Trstenjak:

'...the risk that transfer of asylum seekers to another Member State for the purpose of examining their asylum applications will expose them de facto to treatment which violates fundamental rights and human rights can never be completely ruled out. ${ }^{, 72}$

The CJEU expressly confirmed the conclusion of the Advocate General that applying the Dublin Regulation on the basis of a conclusive presumption is incompatible with a Member State's duty to interpret and apply the Regulation in a manner which is consistent with fundamental rights. ${ }^{73}$ It cannot automatically be assumed that a transfer under the Regulation will be compatible with EU fundamental rights, regardless of the situation in the State with primary responsibility. ${ }^{74}$ Therefore, the CJEU has affirmed that a conclusive presumption, that other Member States will live up to their fundamental and human rights obligations, is not allowed. $^{75}$

This decision may be problematic for the EAW system, which is based on mutual recognition and mutual trust. A conclusive presumption that upon surrender the issuing state will respect and protect the requested person's fundamental and human rights, does not allow for the possibility of conducting an examination into the actual situation. Therefore, it cannot be "completely ruled out" that a requested person will be transferred to another Member State despite a real risk that his or her fundamental Charter rights will be violated. ${ }^{76}$ It is clearly arguable that national implementing legislation which enacts such a conclusive presumption is incompa-

\footnotetext{
${ }^{71}$ Gisèle Vernimmen-Van Tiggelen and Laura Surano, Analysis of the future of mutual recognition in criminal matters in the European Union: Final Report, 2008, p. 20.

72 CJEU, Opinion of Advocate General Trstenjak (fn. 7), margin no 130.

73 CJEU, N.S. v. Secretary of State for the Home Department (fn. 5), margin no 99; CJEU, Opinion of Advocate General Trstenjak (fn. 7), margin no 131.

${ }^{74}$ CJEU, N.S. v. Secretary of State for the Home Department (fn. 5), margin no 80-81 and 99; CJEU, Opinion of Advocate General Trstenjak (fn. 7), margin no 129.

${ }^{75}$ CJEU, N.S. v. Secretary of State for the Home Department (fn. 5), margin no 100 and 105.

${ }^{76}$ CJEU, N.S. v. Secretary of State for the Home Department (fn. 5), margin no 99; CJEU, Opinion of Advocate General Trstenjak (fn. 7), margin no 131.
} 
tible with the executing Member State's duty to interpret and apply the Framework Decision "... in a manner consistent with fundamental rights". 77

\section{Rebuttable presumptions and EAW surrender procedures}

Although the CJEU found that the operation of a conclusive presumption in relation to asylum applications under the Dublin Regulation was precluded, it decided that the presumption required by 'mutual confidence' and underlying the Regulation, that the treatment of asylum seekers in all Member States complies with fundamental and international human rights obligations, “...must be regarded as rebuttable."78 Therefore, Member States should proceed on the rebuttable presumption that the asylum seeker's fundamental and human rights will be observed in the Member State with primary responsibility. On the basis of this model, an asylum seeker should have the opportunity, prior to a final transfer or removal decision being made, to present evidence rebutting the presumption that another Member State will abide by the Charter, the Geneva Convention and the ECHR.

In her opinion, Advocate General Trstenjak stated that proceeding on the basis of a rebuttable presumption seems reasonable, given the high level of human rights protection which is legally ensured under the Charter and the ECHR. ${ }^{79}$. However, the Advocate General warned that any Member State operating a rebuttable presumption "...must observe the principles of effectiveness, according to which the realisation of the rights conferred by EU law may not be rendered practically impossible or excessively difficult". 80

Likewise, in the context of the EAW surrender procedures between Member States, it would be entirely consistent with the Framework Decision if executing judges proceed on a rebuttable presumption that an EAW has been issued in good faith and the person being surrendered will be treated in a manner that complies with fundamental and international human rights. To take such an approach would formally satisfy a Member State's sovereign duty to protect fundamental rights by ensuring an accessible opportunity for evidence in rebuttal to be presented and an objective risk assessment to be made. ${ }^{81}$ At the same time, this approach does not preclude altogether the operation of principles such as 'mutual trust' and mutual recognition of judicial decisions, upon which the cooperative EAW surrender procedures are based.

In line with the CJEU asylum case, not only should the presumption that all Member States will comply with fundamental rights be regarded as rebuttable by

\footnotetext{
77 CJEU, N.S. v. Secretary of State for the Home Department (fn. 5), margin no 99; CJEU, Opinion of Advocate General Trstenjak (fn. 7), margin no 131. This issue is relevant to two cases which are pending references for a preliminary ruling before the CJEU: Court of Justice of the European Union (CJEU), case C-396/11 (Radu /Romania) and Court of Justice of the European Union (CJEU), case C-399/11 (Melloni v. Spain).

${ }^{78}$ CJEU, N.S. v. Secretary of State for the Home Department (fn. 5), margin no 80 and 104.

79 CJEU, Opinion of Advocate General Trstenjak (fn. 7), margin no 133

${ }^{80}$ CJEU, Opinion of Advocate General Trstenjak (fn. 7), margin no 134.

${ }^{81}$ It may not satisfy the principles of effectiveness, if rebuttal evidence was required in the issuing state when an EAW (or a European Evidence Warrant (EEW)) is being issued.
} 
the requested person, but Member States, including national courts, on their own motion should be prohibited from transferring a requested person in relevant cases. Where the political and judicial authorities of the executing state know or ought to know, based on receipt of credible reports and information via the EU system, that there are systemic deficiencies in the criminal justice system of the issuing state, this may amount to substantial grounds for believing that the requested person would face a real risk of being subjected to fundamental rights violations, such as inhuman or degrading treatment in detention. ${ }^{82}$

\section{Conclusion}

Both the Common European Asylum System, consisting of the Dublin Regulation and the relevant directives establishing minimum standards, and the system for the mutual enforcement of arrest warrants created by the EAW Framework Decision, are examples of EU Member States having 'mutual obligations' ${ }^{83}$ and mutual trust in one another. In order for both the asylum and the surrender systems to operate efficiently, and with certainty, it must be assumed that Member States are applying fundamental and international human rights standards in collectively working towards the creation of an area of freedom, security and justice. Therefore, the CJEU asylum case should be used to resolve the debate about the status of fundamental and human rights in connection with the operation of an arrangement for surrender within the EU.

On the basis of the principles set out in the asylum case, the drawing of a conclusive presumption, that the issuing Member State will respect a requested person's fundamental and human rights, should be prohibited. The presumption of mutual trust must be viewed as rebuttable. Following the decision of the CJEU, it is necessary to ensure from a legal point of view that national implementing legislation promotes both the issuing and the executing Member States' duties to interpret and apply the Framework Decision in a manner which is consistent with the Charter, the ECHR and general principles of EU law. In order to promote certainty of law, this would ideally be achieved by inserting express provisions in the EAW Framework Decision. The Framework Decision should explicitly require national implementing legislation to establish the opportunity for substantial rebuttal evidence to be raised by the defence, or on the national executing judge's own motion, if appropriate, against the execution of an EAW on human rights grounds, where there is a real risk that the requested person's fundamental and international human rights will be violated due to systemic flaws, if he or she is returned to the issuing state.

However, in line with the current provisions of the Framework Decision and the conclusions of the CJEU in the asylum case, it is recommended that at least national implementing legislation should clearly establish a rebuttable presumption, as stated

\footnotetext{
${ }^{82}$ CJEU, N.S. v. Secretary of State for the Home Department (fn. 5), margin no $88-94$.

${ }^{83}$ Daniel et al (fn. 54), p. 590.
} 
above, that the issuing Member State will guarantee the fundamental and human rights of those being surrendered, in compliance with the requirements of the Charter, the ECHR and general principles of EU law. Both the Luxembourg and Strasbourg Courts have confirmed that diplomatic assurances and ratification of conventions and treaties alone may not provide a sufficient guarantee against violation of these rights in practice. ${ }^{84}$ A rebuttable presumption would mean "...the end of the concept of absolute mutual recognition", 85 but would still allow the principle to operate in the absence of significant evidence to the contrary.

In the case of a requested person who has been convicted of a serious offence and has fled from justice, Article 4(6) of the Framework Decision allows for the executing judge to refuse to execute the EAW on the basis that the executing Member State will "...undertake to execute the sentence or detention order in accordance with its domestic law". 86 The rationale of this provision was to increase the prospects of reintegration into society on expiration of the sentence. ${ }^{87}$ On the face of it, this provision provides a reasonable alternative to surrendering a person to a state where the criminal justice system is in some crisis. However, in the case of a requested person who, for example, is a suspect of a serious offence committed solely against the domestic law of the issuing state, and who is able to present cogent evidence in rebuttal which demonstrates systemic deficiencies giving rise to a serious risk that his or her fundamental rights will be violated if surrendered, the options are more limited: either, the warrant is executed in a manner that is not in compliance with the Framework Decision or fundamental and human rights obligations; or the warrant is refused, at least until such a time as the situation in the issuing state has apparently improved, leaving open the possibility of forum shopping by non-resident criminals.

A fair and effective solution to this problem must be found if rebuttable presumptions against execution of an EAW are to become an acceptable reality. The European Supervision Order (ESO), which allows a pre-trial non-custodial supervision order to be transferred to the Member State where a suspect is normally resident, may provide an alternative to surrender and, often lengthy, pre-trial detention. ${ }^{88}$ The ESO has the potential to reduce the duration of detention in the issuing state to the period of a court trial only, and ensures the on-going involvement of the executing sovereign state. ${ }^{89}$

\footnotetext{
${ }^{84}$ CJEU, N.S. v. Secretary of State for the Home Department (fn. 5), margin no 81 and 103; ECtHR, M. S. S. v. Belgium and Greece (fn. 1), margin no 354 and 359. See also Plaintiff M70/2011 v. Minister for Immigration and Citizenship; Plaintiff M106 of 2011 v. Minister for Immigration and Citizenship [2011] HCA 32 (31 August 2011), margin no. 67; and see also European Court of Human Rights (ECtHR), Saadi v. Italy, Application no. 37201/06, Judgm. 28 Feb. 2008.

${ }^{85}$ Peers (fn. 64).

${ }^{86}$ Article 4(6), Council Framework Decision of 13 June 2002, OJ 2002 L 190/1.

${ }^{87}$ Court of Justice (ECJ) 17. 7. 2008, case C-66/08 (Szymon Kozlowski), margin no 45.

${ }^{88}$ European Commission, Report from the Commission to the European Parliament and the Council on the implementation since 2007 of the Council Framework Decision of 13 June 2002 on the European arrest warrant and the surrender procedures between Member States [SEC (2011) 430], COM [2011] 175, 11 April 2011, 7.

${ }^{89}$ See the Council Framework Decision 2009/829/JHA of 23 October 2009 on the application of the principle of mutual recognition to decisions on supervision measures as an alternative to provisional detention.
} 